\title{
PATRIOTISM BETWEEN NATIONAL IDENTITY OF PEOPLE AND NEOLIBERALISM
}

\author{
Radomir D. Đorđević ${ }^{1}$, Andon G. Kostadinović \\ ${ }^{1}$ University of Prishtina, with temporary headquarters in Kosovska Mitrovica, \\ Faculty of Philosophy, Kosovska Mitrovica, Serbia \\ ${ }^{2}$ Faculty of Law, Security, Management, "Constantine Great, "Nis, Serbia \\ radomir.djordjevic@ @otmail.com, dekan@konstantinveliki.edu.rs
}

\section{Professional Paper 10.5937/jouproman8-25374}

\begin{abstract}
The paper deals with the problem of patriotism as a national identity of peoples and neoliberalism, as increasingly present in developing countries as well as in other countries. Today's meaning of patriotism has largely darkened everyone's struggle against everyone, especially the world market. The emergence of multinational companies and the increasing presence of the imposition of certain conditions in many countries in political, military, social, economic and every other spheres is more and more present.

The authors in theory view this situation in our country as well, and then globally.They consider that patriotism, as an internal state or consciousness of a nation about itself, has been greatly altered in favor of so-called neoliberal capitalism, which enters into every country that permits it, or vice versa - by force of imposes different behavior.

Neoliberalism is an old-fashioned approach to expressing a society that is trying to transfer its freemarket behavior to other countries, thus transforming one country or transforming it into a different-type colony with the help of the domestic political elite.
\end{abstract}

Keywords: patriotism, neoliberalism, peoples identity, liberalism, world market, globalism.

\section{INTRODUCTION}

\section{PATRIOTISM AND HOW TO TAKE IT TODAY?}

Patriotism, in its original and historical sense, is a very old term to denote the feeling of a people and their belonging to that people. Patriotism is related to the ethno genesis of the people ${ }^{1}$, its beginning and its historical origin. It changed from time to time with the change in the historical development of the ethnic group itself, from the once strictly integrated notion until now, where patriotism is perceived differently. This is especially true of poor countries, where patriotism is less and less an "eventual violation of the rules of the individual", and to this day, when patriotism has lost or is about to lose, in the coming times, which changes in line with the development of human kinds of.

\footnotetext{
${ }^{1}$ People are a community in a "natural" sense, as a higher form of tribal unification. Subordinated to biological and sociological laws of origin, development and extinction. It's a great mix of people who live in one country, area, city. Space is an environment in which reunification takes place, which inhabits and defines a common destiny and culture. In this sense, "people" (Greek "othnos" represents that type of community that is significantly related to the rural way of life (...) on the other hand, the old German legal and political terminology distinguished "natural people" (naturvolk) from the people of the state ("Staatsvolk"). See more in Ljubomir Tadic, "The Science of Politics", Library "rad," ed.rad.org. "Rad," Belgrade, 1988, pp.198-199.
} 
To some people patriotism is just an ordinary messenger and in order to tell someone who he really is and to another, it almost means nothing, but would lose everything in his or her own country in order to succeed in its material sense, no matter where it might be found. Thus, cilia is no longer caring for everyone at his hometown, his home country, and looking at his life and in his parents and in order to succeed in a new environment, whether or not the thin environment accepts it. It is more difficult, especially in this case, if the tasked individual is of a different race ("colored") and is a minority different in color or other characteristics than most others. Also, the issue of such an individual or a group of them and even more of their companions in one place is seriously condemned by the majority because such a majority (usually white) does not trust them because they believe that such a minority or an individual is not entirely an individual to be part of and it never will be. The racial problem is more and more pronounced, first in Europe by the German Nazi Reich who are not Jews, and then in, a classic example of the present-day USA, THE GOD OF THE WORLD AND WHERE AND UNDER THE CONSTITUTIONAL GUARANTEE THAT GUARANTEES ALL RIGHTS WITHOUT GENDER, APPEARANCE, is usually decided in court in favor of the white majority. Patriotism in this case, on the one hand, defends its self as an ethnic substrate and fears the "other" who is different from them, and whom they do not know enough. Again, religion is also mixed here, which can also contribute to intolerance between people of different skin colors, although the Bible says differently, "Brother is a brother of whatever faith he was." However, despite the serious incidents that occur on this basis, the conflict between the patriots and newcomers is sometimes suppressed, mostly by the help of the law of a particular state. Losing or abolishing slavery in the United States, THE RACIAL DIFFERENT CYTOSTOME IS REDUCED AS MUCH AS POSSIBLE, but he did not and lost. Even today, there are hidden, secret associations, which by force seek to expel "newcomers" from their regions. It is a particular problem if a possible marriage of two different entities also occurs. Such a marriage will certainly not be able to survive in the environment in which he came, as he will always receive derogatory names and his wife of a different skin color (white woman) will be exposed to all kinds of insults and may be harmed (her, her husband or their children). Hence, patriotism is something "sacred", for some and religious in a sense, for others, merely the desire to earn something more in the new environment than in their home country. All of them were connected by the same primitive language, the common space in which they lived, and the same origin of the genera, fraternities and tribes, which belong to the elemental and characteristic factors of the characteristics of a people. Especially cherished expression of love for his fellow man and environment contexts in which they lived. From these initial commonalities, to the expression of self-awareness about one and only collectivities, and which in our place is denoted as love by the union of "TRUE" and common life, the more and more international term patriotism has become common. 
However, fathers leave in itself, it seems, and an even closer trait - a subjective expression of love for his people, and, in a broader sense, the collective and identical behavior of all individuals to the community -motherland, and we often denote the expression " native lumps. " Through his upbringing in the family and then within the wider community. The individual acquires certain knowledge about his or her origin and the community to which he lives and belongs, and thus protection and security. Therefore, faithfulness to itself is something that implies, because natural, and therefore love, that is born of its community - the people from which it originated. Consequently, faithfulness to it is something that is implied, which is natural, and therefore love that is born of its community - the people from which it originated.

\section{LEAVING STATE CREATION BY THE OLD MODEL I REPLACING THE NATIONAL STATE CREATION}

In the period from the sixteenth to seventeenth centuries, another form of communion appeared and almost reversed the whole world. It is the formation of nations, rather than nations or national communities. It happened in Western Europe and they took the name of the nation. ${ }^{2}$ Gerhard Leibholz points to political distinction - "ordinary people," multitudes, but people in the plebiscitary meaning of immediate democracy. On the other hand, parliamentary representation also differs. As for the nation, Leibholz believes that "the people are transformed into a "nation" as soon as they become aware of their independent political and

\footnotetext{
${ }^{2}$ Leiholz, G. (1974). "The Structure of the Problem of Modern Democracy", Frankfurt, p. 247-262. 14
}

cultural values, and substantially confirm their existence as an independent concrete entity". ${ }^{3}$ Furthermore, according to Tadic, G. Leibholtz, who "tells the nation that she is the expression an act of self-awareness and will, not a mystical irrational substance". The question that follows from this statement of the thesis about the nation is, does the creation of nations, on the other hand, lose the sense of love for the fatherland, that is, patriotism? The question we have asked has its twofold answer. On the one hand, patriotism is not lost with the creation of nations, and on the other hand, this feeling does not cease to be lost, because it is somehow biologically implanted in every member of one nation.

Certainly, this second meaning or assertion can be debatable, since in the issue of patriotism the "biological" cause is not decisive, because there are opposite examples. One can only speak of a certain weakening of the feelings of patriotism in the clade and with certain changes that the world in the meantime recalled. Hence, people are still the only and real option on which all humanity is based. ${ }^{4}$

\footnotetext{
${ }^{3}$ Leiholz, G. (1974). "The Structure of the Problem of Modern Democracy", Frankfurt, p. 262.

${ }^{4} \mathrm{~A}$ good example of such a claim is the example of Austro-Hungary, which was made up of several peoples who were imposed a higher will to live in a common state. Yet in a state like this, patriotism was far from the actual patriotism and constituted a dual monarchy. Already in World War I, recruited for the Austro-Hungarian monarchy, the peoples who lived under the dual monarchy displayed desertion on the battlefield, not wanting to war against their Serb brothers.
} 
Nations are the product of a new socio-political system - capitalism, which starts from capital, as the basis of the wealth of the nation-nation. Although at first many new nations seemed rather inhomogeneous with the passage of time, the diversity that was at the beginning was increasingly lost, to finally bring about new sociability, in the form of wider homogenization of similar peoples by naming new peoples as the nation. ${ }^{5}$

It can be assumed that capitalism, no matter how striving for the integrity of the nation and the unification of former peoples, has not fully succeeded in its homogeneity, creating the notion of a nation, sometimes a diversity of peoples by origin, race, language. In fact, a nation is maintained by the application of the created legal regulations and, on the contrary, by unbundling, which is usually punished by various means of pressure to provoke the dissolution of a former nation. ${ }^{6}$

\footnotetext{
${ }^{5}$ Nation (Lat.nasci, which means being born). A community that speaks the same language and is imbued with an awareness of mutual belonging and integrity in relation to other nations. A nation has a common territory, soil, land as the cradle of life and a guarantee of survival, its own language, national institutions (family, traditional customs institutions, typically ethnic, cultural institutions) and the state with a system of political institutions. However, despite all the above, a nation does not always have an ideal coherence, if it consists of several groups of similar peoples (the example of the former Yugoslavia) and hence, more and more, the nation is identified as a note: "all citizens" and is the closest to the term ethnonation. ${ }^{6}$ This is especially evident today in the example of Europe, where an attempt was made to artificially unite many former peoples, in order to awaken the peoples' term again today. Let us highlight the example of present-day Spain, Ukraine, but also the pillars of nation-building in Europe, France, England, Germany, where individual riots are also created against official authority and national separation demands. In Yugoslavia, this ended with the civil - ethnic war and the disintegration of the once homogeneous "Southern Slavs" nation. Today it is a state divided into a number of small ethnic groups, which emphasize their ethnic authenticity.
}

He also had processes that could be called "reversible", that is, to create modern nations from formerly united nations, to transform into nationalist ones - in their negative sense, showing that some of the created nations would defend their national unity, even by methods which are an exception today for the communities that consider themselves to be culturally civilized. The former "notion of love for one's own people" is largely replaced by the term "nationalist" and which greatly distorts the notion of a nation as a freely united community of nations. The nationalist notion had an ideological basis, and so it continues today. Particularly at stake are all those who have retained the notion of national unity, national unity, people's faith and all that resembles the unique past of a nation. On the contrary, the term nationalist is widespread, which has a distinctive negative meaning and relation to another nation. Nationalism spreads hatred among themselves, and everything else that it uses to bring discord to the older tribal groups of one nation and create a conflict between them. The outcome of all this will be the "victor" who serves and obeys orders from foreign or foreign powers that still have their national power in their country. Certainly, in these countries, too, the nation relies on a law - a constitutionality that does not allow for the separation of peoples. How long such coercion will last is unknown for now, but it is in one swing that is difficult to control.

All such activities greatly change the image of nations and national unity, and that builtup "homogeneity" on a national basis cannot be overthrown. 
Yet, this attitude is even more apprehended on the negative side, on the one hand by supporters of nationalism and on the other, by ethnic groups, who want to be "on their own" and take care of their own future. During the twentieth century, two St. and the real causes of which were not the conquest of territories as much as the increasing unification of those ethnic groups that remained free or united, under duress, and by external political factors led to their being united and then reunited with military resources by the powerful. As an example, we can cite - the breaking down of the Warsaw Pact, the fall of socialism, and the transition of some countries from that political-war bloc to the other - the NATO Pact and then the formation of a United Nations or a community of nations in Europe - abbreviated to the EU. Although the great powerful struggled to finally form national communities in the 20th century, they remained part of the people's groups that were still free today and led a free life as nation states. On the other hand, supporters of the national and thus nationalist in certain segments have caused a number of problems. The socalled new age, popularly called "Newage." This vessel is called the" ... casting of a new world order." (M. Ferguson ). It begins with partial wars across the earth's ball, mostly in smaller countries without any defense, primitive people's groups, weaker or less weaker nations whose will for freedom breaks down in the socalled creating a global new order or, in short, globalism. Creating such an order, which at first abounded with a series of promised and alluring offers for many countries to join such a social system, is a global phenomenon of the removal of more powerful countries and where they would manage all the resources that would come from the rights of the stronger or to bribe the political structures of some of the poorer countries. Globalism was on the verge of winning and realizing its plan for the world as a global village (Makluan: 1968). To this end, many socalled organizations that call themselves "non-governmental organizations" (and actually aren't), we would say, sort of "Trojan horses" of the new world order. The notion of the so-called. Civil society, which at first almost no one understood what it would mean in practice. However, in the end, it all came true, that behind this term was hiding the power of oligarchic capital to undermine fragile countries and to accelerate their membership in global flows. These socalled. "Non-governmental organizations" use all legal and illegal means, ranging from freedom and human rights to their choice, to the right to democratic opinion, to the right to speak publicly, or to create individual groups or like-minded individuals in the area of intimacy, sexuality - the gay group as a free right to pursuing the love of like-minded persons (lesbianism, sexism, transvestism, etc.) Non-governmental organizations, assisted by world magnates, run their own affairs of interest in each country and are assigned to them in order to achieve their goals. Any deviation from this is vehemently denied by the public as the heresy of the majority over the minority and suppressed by the power of its cartridges, which are usually outside the borders of the country concerned. Everything that is a product of old creation and behavior and artifacts is distorted or ridiculed as "demodes" and does not fit the modern world. The world's powerful want a unified world and one in which they can rule at will and subjectivity. 
As an example, we can cite a recent example in our country, the former Yugoslavian vein area - specifically in a newly created small country of Montenegro, where the judicial process is trying to shrines SPC - Serbian Orthodox Churches in Montenegro are under the regime of statehood of Montenegro. Thus, in the domain of religion, the Serbian church would lose its centuries-old independence, as the state of Montenegro claimed the legitimacy of church property until the 18th century. If he cannot prove it, then all church property would belong to the state of Montenegro, which is protected by the NATO bloc. Peoples' demonstrations are still ongoing, and it is unknown how the conflict will end and for whose benefit.

\section{NEOLIBERARISM AND BEGINNING TO RETURN THE OLD MODEL}

We chose this title, first of all, from the current situation in the world, and when it became clear that with the patriotic and national-nationalist attitudes of the "New Age" association, it did not go all that smoothly in the world of business and when the market itself was stronger. This once terminological term in the world of capitalism reappears under a new cloak and in line with the times we live in. It could also be said: "Neoliberalism is the past, let's turn to the new neoliberalism." This is not just a play on words, it is trying to evoke the present situation in the capital world and which has failed in its intentions to master the whole world. Even today, there are many countries that are both powerful and large in population without advocating such a division of the world. Thoughts of the Second St. war that everything belongs to the past, that humanity has finally realized the causes of its calamity in the Second St. war, and many of the victim and the genocidal politics of the country that the war began. This did not happen, however, because symbolically, it was again "hit against the hard wall" by humanity, by inhumanity. And as in the letters of St. Nikolaj Velimirovic, who warns us that in the twentieth century we have a collision of the Western culture man "Superman", on the opposite side - the eastern one, we have " God-man". Collision of these two "fictional personality, you would be edited in swept in a philosophical sense, but what would an ordinary person could understand in real terms. One thing is clear, however, the "Superman" from the West failed to put the whole world under his control because he had a "God-man" against him - who protected him from all the evils that succeeded in freeing himself, and gradually they are destroying the existing world. With the disintegration of the former socialist USSR, a new power was born in the East, a powerful Orthodox Russia, followed by a multi-million dollar dual system, like India, with its large population, which form one of the groupings of the anti-block division of the world. These countries are, first and foremost, peaceful and do no harm to anyone in their strength or anything else. They want normal trade cooperation on an equal footing, however small or insignificant a country is. These countries do not tend to reciprocate smaller or imposing its will on other countries, but their equality of small and large countries. Such a policy is certainly receptive, than he is, offered aggressive West and salvation is his power - all before him their weapons. 
Hence, many new imperial wars by individual countries led by the US, England, France, Germany, and which turn into some kind of peace international forces, which protect the fallen countries. Of course, there are, but more so are those other stripped down parties, where individual countries from the West demonstrate their power over the world's poor countries, and press them with their hegemony. That is, unfortunately, and succeeds, but also expands the high resistance of such poor countries imposed such a government. The wars that arose at the end of the twentieth century in many countries, and on almost every continent, were triggered by a concerted action by world "policemen" (the United States), followed by those countries that adopted such a policy of force in international relations. ${ }^{7}$ The bloody wars that took place near the end of the 20th century triggered large migrations of populations from their hearths to other European countries, and the refugees, who think that the refugees live, will find their lives better and more bearable. However, this is not the case, as it ended first on the first wave of refugees, to be kept today by raised barbed wire fences and armed soldiers. These old and wealthy colonial countries realized where it was headed, and stopped the influx of refugees where they found themselves. Serbia is one of the countries with the largest number of refugees in Europe and with which our country provides accommodation and food.

\footnotetext{
${ }^{7} \mathrm{We}$ remember the lawlessness of the NATO-Pact attack on the former Yugoslavia, which, contrary to the resolution passed by the UN Security Council, bombed the then Yugoslavia, which separated the province of Kosovo and Metohija, which was part of Serbia, from it. With the new UN resolution 1244, the bombing of Serbia and Montenegro of 78 days was stopped. The bombing of the then FRY involved 19 NATO countries.

But after this situation, as we have described, and which is still present today, the beginning of the new century enabled the return of the old acquaintance of capitalist production, which was based on: "higher work, less pay" and all in the name of the so-called the doctrine of neoliberalism, which was invented for the minority to rule over the minority with their capital and where social justice was measured "how much money do you have in your bank account".

Neoliberalism does not know the diversity of peoples or nations, history, ideology, politics, economy, which may be quite different in the current circumstances. Neoliberalism does not submit to national unity and national homogeneity of one nation, it divides people only by the principle of how financially powerful you are and thus influential in the world economic circles. Religion, culture, civilization of other nations does not interest him, because he does not want to, nor is it his ultimate goal. It aims to succeed in a worldwide manipulative marketplace where transactions are conducted in a hidden form, to show who knows where else and to jeopardize any production that goes out of their way. So ( John Galt: 2019) among other things, says: "Critics of neoliberal capitalism very rarely clearly define what neoliberal capitalism is, and why it would be negative at all, i.e., how such a system causes adverse effects on society, and where it today ... and in the world see they neoliberal capitalism". 
It was obvious the real intention of the critics, who are mostly of previous good wages're black for the job, is to die "conscience" of the powerful, and then all displays in a calming state, that all will all go well, because uneducated workforce, and he does not know who he is working for and how much he is working for, nor can he ask his employers about his earnings, work in difficult conditions on the strip, and part-time, and understand everything about neoliberalism. The neoliberal model of capitalism is of recent date, though it originated a long time ago, from the beginning of the 16th century, but in the new conditions and in the age of powerful technologies, it has proven to be a frightening wave that will flood the world with its "tsunami waves". "Neoliberal capitalism would be an economic system based on a free market without state control, and so neoliberals oppose state interventionism, subsidies, taxes, welfare state elements, public education and health, state banks, etc. and they support market liberalization, privatization and reducing the dependency of the state apparatus."( John Galt, too ). From this definition of neoliberal capitalism, one can clearly see its scheme on which its future in the field of state power, public education, and health, state banks is based, and support the hearty liberalization of the market in every respect. Not only does this definition contradict all the realities of today, it defies every common sense, because it does not place man on the pedestal of the throne he should rule as the most conscious being on the planet, but prepares the ground to subordinate everything to himself and every part of his rule by any whom, not belonging to him, but to powerful corporations or as they were called in the time of Marxist rule: capital trusts. In a word, as part of the

world, if we do not preserve our masters of liberty from such predators of human descent, we will experience the plight of the neolibers, who have never been in the so pronounced power of the minority over the majority. "We live in the conditions of an unregulated free market, wild capitalism, low taxes, and minimal government intervention in human relations and very low levels of government spending." (John Gult, ibid.) .

At the same time, the "Web-tribune.com", April 26 one of the headlines was: "The neoliberal capitalism: a global scam that made the super rich even richer." ${ }^{18}$ Proponents of neo-liberalism have achieved great success by funded rich millionaires, certainly not financially but politicians certainly. In economic terms, they have fallen further and come almost on the brink of collapse. It is, in fact, borrowing, when earnings have stagnated and have made their income even worse with banks. Debt has been growing, and with it all other troubles - especially social ones. Banks that were "split off from the state government and left to a completely free market, profited from free regulation in the area of bank lending policy. The banks were degressing the banking sector, which accelerated the growing inequality among the people, - which was also established by the UN, that is, under the slogan - that the economy was free to grow at a lower rate. The policy of the neoliberal state was to eliminate the deficit and stimulate the economy, which was counterproductive.

\footnotetext{
8 "In 2012, the 100 richest people in the world made $\$ 241$ billion. Now they are" heavy "\$ 1.9 trillion (a billion billion): slightly less than the annual GDP of the UK." / Wev-tribune .com, 26 April 2016./
} 
Once successful, the attempt was repeated numerous times. "It has nothing to do with economics. The only thing that has to do with it is the power of the UN: Repeating some old lessons about fairness and participation is the only way to finally overcome the crisis and move on to sustainable economic development." (WebTribune.com, April 26, 2016.). This warning, however seemingly reasonable, is in reality unrealistic because it does not correspond to the time given. What kind of participation and fairness can be talked about in a world of injustice to all the poor, and where a rich minority manages the world behind their glassfacades of buildings and well-armored safes with their "hard" acquired assets - wealth. But how did they get it all? "Here are some moves: reducing tax rates and taxes imposed; the government's refusal to offset a decent portion of its mining and land revenue; privatization of public property and creation of an "economic ramp"; wage liberalization and the destruction of collective bargaining." / Web-tribunes.com, April 26, 2016/. Behind it all, politics remained, which made the rich even richer, and by contrast, the policy of impoverishing and already impoverished sections of the population was welcome for the world's powerful. Interestingly, such a policy could not have been foreseen, or, if it could, then it was very cleverly hidden from all others interested in making similar moves. On the other hand, the well-known economists Friedrch Haiek, ${ }^{9}$ Milton Friedman and some of their companions

\footnotetext{
${ }^{9}$ Hayek, F. (1935)., prepared a collection of papers (he wrote an introductory and concluding essay) entitled Collectivist Economic Planning: Critical Studies on the Possibilities of Socialism, as a contribution to a fuller understanding of the book "The Path to Slavery".
}

considered speaking out loud and in thousands of business schools to the IMF, the World Bank, the OECD, and a number of governments, argued that the rich were being taxed as little as possible, defending workers and it redistributes wealth, and thus the wealth itself and the country itself will be more prosperous. Hence, any attempt to break poverty and inequality would contribute to market efficiency or, figuratively speaking, "the coming tide that lifts all ships." So, from everything, we can conclude the following: "The demands of the ultra-rich have been translated into sophisticated economic theory and translated regardless of the outcome. In addition, the complete failure of this global experiment does not prevent it from repeating itself. It has nothing to do with economics. The only thing that has to do with power is at the core of everything is the connection between ties and power, which give neoliberalism the power it possesses - coated in a new suit, and so that the poorer classes do not recognize the true "killer" of their poor life.

But after this we are left with the question of what happens in such cases with patriotism, love for the homeland, especially if the state does not take care of its population in the way that the population should be satisfied with such a state. We think that in today's conditions it is almost impossible, because in the world, it depends not only on us, but also on those countries that dictate economic conditions. Do small states have anything to look for and are they allowed to laugh in such a power relationship? In our view, they should, not "should they". The relationship between rich and poor is so interconnected that they cannot do without each other. 
Wealth comes from the poorest, their labor, whether light or heavy, and on the contrary, the rich would not be without their exploitation. On the other hand, poverty will continue to grow, because it is so large that the "richer" may not make all the poor and their lives more bearable, and may not want for their own and vain reasons. Is there behind the "factor of consideration" of the rich, that anything that is supposed to be developed, develops in accordance with the principles set by the richer. They set or set daily wages and pay levels for the working classes. Somewhere they are bearable, somewhere average, and much more at the level of one day's costs. Does this mean that everything also depends on the geography of the soil, the conditions in the country concerned for the placement of capital, or the biological and racial traits of the people themselves, and where "workers" with different skin color are paid less, but more exploited, as a simple workforce? Neoliberalism has entered the butter door, to enter all doors today and wherever it wants, because it disposes of "its capital" which it has acquired when possible. Today, the same is being attempted only in the changing conditions of the world economy, but which again depends on the powerful of neoliberalism and which dictates the conditions of taking out loans or financing certain facilities that will primarily use them. Such infiltration, directly or not, is revealed only after a certain period of time by a change of policy in power in the country concerned and under what conditions it has allowed neoliberal perceptions of the country's economic dependence to be expressed.

Patriotism in such conditions is difficult to recognize in such changed conditions, when all resources are in the hands of foreigners or "vultures" of capitalist wealth on the basis of a neoliberal view. Justice and justice do not exist in neoliberalism, or if it exists, it is wholly minor and quickly transcends it. Patriotism in such conditions, however, persists in those strata that are independent of any influences of neoliberalism. These are usually peasants, freelancers, freelancers, and almost untouched by the politics of neoliberal understandings. In a word, once implanted in the hearts, patriotism is difficult to lose, to many to whom it amounts to a great deal, and to those who barely make ends meet. To them, such a position is unbearable and patriotism does not affect them as much as other more independent sections of the population. On the one hand, impoverishment policy creates a complete disinterest in political love for their country and there are more and more people who abandon it in the desire to get rich on the other side as soon as possible. With the increase of their power (not all), the desire for a homeland, where they came from, still arises, and the native soil is mentioned in every seat they gather from time to time and to evoke their memories from their native land. Those who have not been able to get rich in a foreign country, patriotism is just a word for them and not something that sometimes reminds them that they lived in a country of prosperity then, while the new generations do not remember such memories because they were too small to remember where they were born at all.

\section{CONCLUSION}

Patriotism on the one hand, and neoliberalism on the other, are essentially incoherent and incompatible phenomenon. They do not coexist together, except in special cases, if there are exceptional opportunities for cooperation. 
However, such coexistence almost never occurs because of the opposing sides of both sides.

We started with patriotism as the noblest condition of a living being and a single conscious on planet Earth, also called human. Nature has given such a being all the necessary natural resources, to make sense of his life and to work for himself or his family by working. In practice, however, this looks different. Patriotism is mostly felt in days that are in perilous danger for the whole society, and when every individual, as a member of one nation, feels the need or conscience to help another, his or her own generation, tribe or nation as a whole. The state as the largest and governing body takes care of such goals that should be achieved and that family life as well as individuals in such a community be dignified and peaceful. Yet, in real life, this is not so. Although a community has made every effort to achieve such goals, there are always forces that pull back the whole society. On such occasions, society is derided by distorted matter, which cannot be reshaped into a homogeneous structure. Such danger is greatest for the society itself, and usually in such conditions the destructiveness of individuals or certain groups increases, and which may (or may) disable one state for further action. In such circumstances, either the danger is prolonged or the socio-political change occurs. In a word, patriotism in the form we conceived of it, and considered love for the fatherland, can be completely weakened in one moment of weakness of the state, while in times of complete fall of the state, the forces usually do not take care of the authorities that do not care so much about patriotism towards the state to preserve certain political positions and which have emerged from the destruction of state power externally or externally. In all situations, neoliberalism behaves quite actively and aids the option most suited to achieving its goals - that is, to enrich its personal capital.

\section{REFERENCES:}

Friedman M., (2006.) Start and economics. "Young America's.

Hayek, F. (1935)., prepared a collection of papers (he wrote an introductory and concluding essay) entitled Collectivist Economic Planning: Critical Studies on the Possibilities of Socialism, as a contribution to a fuller understanding of the book "The Path to Slavery".

Leiholz, G. (1974). "The Structure of the Problem of Modern Democracy", Frankfurt, p. 247-262.

Luskin D., Greta, A., “ I Am John Galt: Today's Heroic Innovators Building the World and the Villainous Parasites Destroying It 1st Edition, Kindle Edition", B y, ISBN-13: 9781118907535; ISBN-10: 1118907531

Makluan , M, (1969), "War and Peace in a Global Village ", Toronto.

Tadic, Lj, (1988), "Science of Politics", Library "Rad", Publishing Company "Rad", Belgrade.

Velimirovic, N., (2018), "On God and on People", "Evrobook", Belgrade.

Web -Tribune.com., 2016.

http: //en.wicipedia . org / wici / Neoliberal Capitalism\% 20). 